\title{
Disturbance of posture in children with very low lead exposure, and modification by VDR Fokl genotype
}

\author{
Natalia Pawlas ${ }^{1}, K_{\text {Karin Broberg }}^{2}$, Staffan Skerfving ${ }^{2}$, Krystyna Pawlas ${ }^{1,3}$ \\ ${ }^{1}$ Institute of Occupational Medicine and Environmental Health, Sosnowiec, Poland \\ 2 Division of Occupational and Environmental Medicine, Department of Laboratory Medicine, Lund, Sweden \\ ${ }^{3}$ Department of Hygiene, Wroclaw Medical University, Wroclaw, Poland
}

Pawlas N, Broberg K, Skerfving S, Pawlas K. Disturbance of posture in children with very low lead exposure, and modification by VDR Fokl genotype. Ann Agric Environ Med. 2014; 21(4): 739-744. doi: 10.5604/12321966.1129926

\section{Abstract}

Introduction and objective. Lead has a negative effect on the central nervous system (CNS), inter alia indicated by disturbance of posture. However, knowledge of the CNS effects at low exposure is insufficient. Individuals differ in vulnerability, possibly because of genetic predisposition. Polymorphisms in the $\delta$-aminolevulinic acid dehydratase $(A L A D)$ and vitamin $D$ receptor (VDR) genes may modify lead metabolism and neurotoxicity.

The objective of the study was to determine whether very low lead exposure affects posture in children, and whether $A L A D$ and VDR genotypes modify the effect.

Materials and methods. In 1996-2001, 108 (age 5-13, mean 6.9), and in 2008-2010 231 (age 5-11, mean 7.9) children from Poland were tested by posturography and blood-lead concentration (B-Pb; medians 50 and $36 \mu \mathrm{g} / \mathrm{L}$, respectively). The children were genotyped for ALAD (Rsal, Mspl) and VDR (Fokl, Bsml, Taql).

Results. There were correlations between posture and B-Pb (sway area with closed eyes: $r_{s}=0.24, P<0.001 ;$ velocity: $r_{s}=0.21$, $\mathrm{P}<0.001$ ). Significant effects (adjusted for the potential confounders height and mother's education) were present already at (In-transformed) B-Pb $\leq 50 \mu \mathrm{g} / \mathrm{L}$ [ $\beta$ (regression coefficient) for sway area $0.025, \mathrm{p}=0.001$ ), and even stronger than at higher levels $(\beta=0.006, p=0.06$, respectively)]. The ff carriers in VDR Fokl polymorphism were more susceptible to the effect of lead on the balance system, while other VDR or ALAD genotypes did not significantly modify the effect.

Conclusions. Effects on CNS, as reflected by disturbances of posture, were present at very low lead exposure (B-Pb $\leq 50 \mu \mathrm{g} / \mathrm{L})$, and the effect was significantly greater at such low B-Pbs than at higher. VDR Fokl significantly modified the effect.

\section{Key words}

balance, Bsml, central nervous system, gene-environment interaction, Mspl, neurotoxicity, Pb, Rsal, rs1800435, rs1139488, rs2228570, rs731236, rs1544410, SNP, Taql

\section{INTRODUCTION}

Exposure to lead is a major risk for the central nervous system. One of the effects is disturbance of posture, which has been reported at high exposures, mainly occupational. Children appear to be particularly sensitive [1-5]. However, it is not known whether posture effects occur at the low exposures present in most developed countries after the reduction of pollution in the last decades [6].

Molecular mechanisms of lead neurotoxicity are complex [7, 8]. Oxidative stress is also a possible explanation [9]. There is a large variation in the susceptibility to lead exposure. Some of these differences may be explained by the genetic background [10]. In particular, polymorphisms in the $\delta$-aminolevulinic acid dehydratase gene $A L A D$, the product of which is the major lead-binding protein in blood (and most likely in other tissues), has been shown to affect blood-lead $[11,12]$ at high exposure, and modify toxic effects on hem synthesis, as well as kidney [11] and peripheral nervous system [13] functions. Also, there might be genetic modification of lead toxicity on CNS; a protective effect for ALAD2 (the variant allele of polymorphism Msp1, also called rs1800435;) and
ALAD RsaI [14] carriers on cognitive functions has been reported, though the findings have varied for different ages and exposed groups, CNS effects and genotypes $[15,16,17$, 18]. Further, there are indications that polymorphisms in the vitamin D receptor gene $V D R(B s m \mathrm{I}=\mathrm{rs} 1544410$ [19, 20]; FokI=rs2228570 [19, 21]) also affect lead toxicokinetics. Moreover, one single study suggests that the genetic variant VDR TaqI modifies the CNS toxicity of lead [22].

\section{OBJECTIVES}

Though still limited, information on gene-environment interaction is potentially important, because it might reveal mechanistic aspects of lead toxicity, make it possible to identify vulnerable individuals, and explain differences in susceptibility between populations with different gene frequencies, aspects of relevance for risk assessment.

We here report on posture disturbance in children with low lead exposure, and potential modification by $A L A D$ and $V D R$ polymorphisms of the relationship between posture and $\mathrm{B}-\mathrm{Pb}$. 


\section{MATERIALS AND METHODS}

\section{Subjects}

In 1996-2001, a cohort of 327 children was recruited in primary schools located in the vicinity of lead smelters in Upper Silesia, Southern Poland. The parent completed a questionnaire (information about sex, birth weight, apgar score, age, mother's smoking during pregnancy, weight, height, development habits and medical history of the child, as well as family income and mother's and father's education), a posturographic examination was made of the child, and blood was collected for determination of B-Pb [5]. In 20062010, 108 (33\%) of the children were re-examined, and a blood sample was obtained for genotyping. In 2007-2010, a new cohort of 231 children from the area was examined in the same way. Hence, the merged genotyped cohort contained 339 children (Tab. 1).

Table 1. Characteristics of the children cohorts ${ }^{\mathrm{a}}$

\begin{tabular}{lccc}
\hline \multirow{2}{*}{ Variables } & \multicolumn{3}{c}{ Cohort } \\
\cline { 2 - 4 } & $1996-2001$ & $2008-2010$ & $\begin{array}{c}\text { Merged } \\
(\mathrm{N}=339)\end{array}$ \\
\hline Boys (\%) & $(\mathrm{N}=108)$ & $(\mathrm{N}=231)$ \\
\hline Birth weight [g], mean (range) & 60 & 55 & 56 \\
\hline Apgar score, mean (range) & $(1,700-4,900)$ & $(1,500-4,450)$ & $(1,500-4,900)$ \\
\hline Age, mean (range) & $8.9(2-10)$ & $9.5(1-10)$ & $9.3(1-10)$ \\
\hline Height [cm], mean (range) & $6.9(5-13)$ & $7.9(5-11)$ & $7.6(5-13)$ \\
\hline Weight [kg], mean (range) & $24(106-154)$ & $132(105-157)$ & $129(105-157)$ \\
\hline
\end{tabular}

Mother's education (\%)

\begin{tabular}{lccc}
\hline$<$ Secondary school & 45 & 32 & 36 \\
\hline$\geq$ Secondary & 55 & 68 & 64 \\
\hline Blood-lead level $[\mu \mathrm{g} / \mathrm{L}]$ & $49.5(26-190)$ & $35(9.0-220)$ & $42(9.0-220)$ \\
\hline median (range), GM & 54.9 & 36.1 & 41.2 \\
\hline
\end{tabular}

GM - geometric mean a Missing data in 1996-2001/2008-2010 cohort (\%): birth weight 7/5, apgar score $12 / 6$, age $2 / 2$, height $5 / 17$, weight $4 / 14$, mother's education $0 / 2$.

The study was approved by Bioethics Committee at the Institute of Occupational Medicine and Environmental Health, Sosnowiec, Poland. Written informed consent was obtained from one parent and oral from the child.

\section{Postural stability}

Exactly the same posturographic methods were used in all examinations. Sway (micromovements of the whole body, which were necessary for keeping erect posture) was quantitatively measured by a force plate with three orthogonal strain-gauge devices (Posturograph SWAY 7.0; Danish Development Products, Snekkersten, Denmark [5, 23]. Spontaneous sway was registered by an unsteady platform, which reacted on the changes of position/ movements of body weight centre. Electric signals evoked by sway were registered and processed by computer software. The testing protocols included procedures limiting/switching off one or more systems for balance control: the subject stood during $30 \mathrm{~s}$. with opened eyes and then $30 \mathrm{~s}$. with closed eyes. Also, information from proprioreceptors was modified: standing on a foam pad ( $15 \mathrm{~mm}$ thick) added to the platform.
Six measures were calculated: 1. mean sway, 2. transversal sway, 3 . sagittal sway, 4 . sway area, 5 . sway velocity, and 6 . sway index. In total, 24 estimates were obtained for each subject. The examinations were performed blindly, i.e. the investigators knew neither $\mathrm{B}-\mathrm{Pb}$ nor genotype.

\section{Blood sampling}

Two $4 \mathrm{~mL}$ samples of blood were obtained from the cubital vein into vacuum tubes (Vacuette; Greiner-Bio, Frickhausen, Germany) containing either lithium heparin for lead determination, or $\mathrm{K}_{3}$ EDTA for genotype assessment. Blood samples were stored at $-20{ }^{\circ} \mathrm{C}$ until analyses.

\section{Blood-lead determination}

$\mathrm{B}-\mathrm{Pb}$ was measured with graphite furnace atomic absorption spectrometry [24], by a Perkin-Elmer 4100ZL instrument (Ueberlingen, Germany). The detection limit was $3 \mu \mathrm{g} / \mathrm{L}$ and the precision $4.4 \%$ (coefficient of variation). In 19962001, the laboratory participated in three interlaboratory quality controls [Center for Diseases Control and Prevention, Atlanta, USA (CDC); Nofer Institute in Łódź, Poland; and Instituto Superiore di Sanita, Rome, Italy], while in 20082010 it regularly participated in two proficiency tests (Lead and Multielement Proficiency, CDC; METOS Program, Instituto Superiore di Sanita), and fulfilled the requirements of the study organizers.

\section{Genetic analyses}

DNA was extracted from blood by the QIAamp DNA Blood Mini kit (QIAGEN, Hilden). Genotyping was performed as described elsewhere [14]. The following single nucleotide polymorphisms were analyzed for ALAD: rs1139488 (also referred to as $R s a \mathrm{I}$ ), rs1800435 (MspI with the $A L A D 1 / 2$ as alleles); and for VDR: rs2228570 (FokI), rs731236 (TaqI), and rs1544410 (BsmI).

For ALAD rs1139488 and VDR rs1544410, assays based on polymerase chain reaction-restriction fragment length polymorphism were used. ALAD rs1800435, VDR rs 2228570 , and rs731236 were determined by Taqman assays with allelic discrimination on an ABI7900 real-time PCR system (Applied Biosystems, CA, USA).

To ensure quality, in each run, control samples for each genotype, as well as blanks, were included. Five percent of the samples were reassayed for each SNP. The distribution of genotypes for $A L A D$ and $V D R$ showed no deviation from the Hardy-Weinberg equilibrium (Fisher's exact test). We excluded siblings in the genetic analyses.

\section{Statistical analyses}

Associations (Spearman's rank coefficients $=r_{s}$ ) were assessed between all 24 posturographic parameters and $\mathrm{B}-\mathrm{Pb}$. The parameters most closely associated with $\mathrm{B}-\mathrm{Pb}$ were sway area, velocity and index, with closed eyes and without foam. We limited our main analyses to the two parameters sway area and velocity, which have usually been the most susceptible ones [23] for the further analysis (the $r_{s}$ cut off values was 0.18 and the significance level $\mathrm{p}<0.001)$. Their relationships with $\mathrm{B}-\mathrm{Pb}$ did not deviate from recti-linearity as assessed by visual inspection (Fig. 1).

Then, potential confounders, effect modifiers and exposureindependent covariates [the child's sex, birth weight, apgar score, age, height, weight, body mass index, and pressure in middle ear (both sides assessed by tympanometry); mother's 


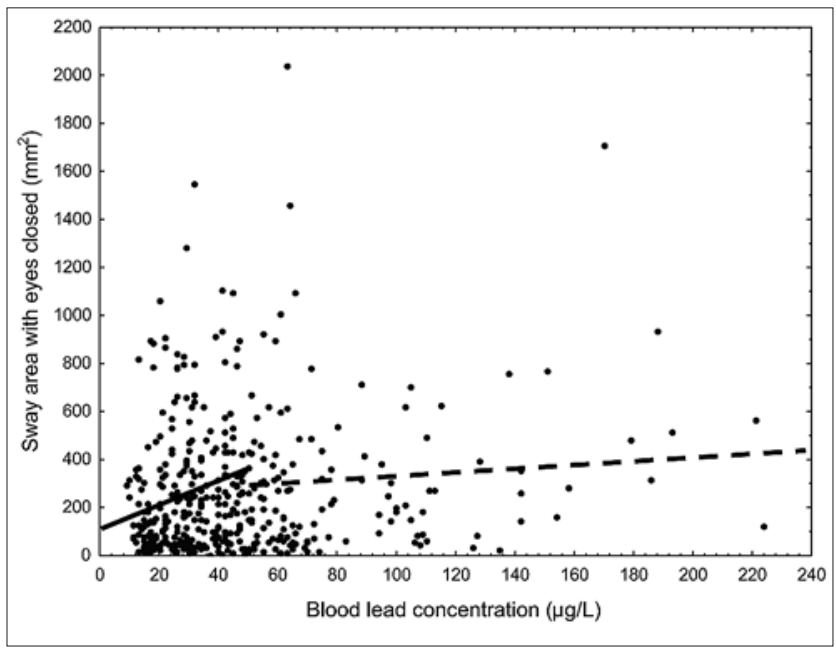

Figure 1. Relationship between sway area and blood-lead concentrations (B-Pb). The data presented are unadjusted. The regression lines denote relationship at $\mathrm{B}-\mathrm{Pb}<50 \mu \mathrm{g} / \mathrm{L}$ (full line) and $>50 \mu \mathrm{g} / \mathrm{L}$ (dashed line), respectively. The slopes were different (see text)

education and smoking during pregnancy] were tested for associations with $\mathrm{B}-\mathrm{Pb}$ and posture. Variables statistically significantly associated with both, or only with posture, were selected for adjustments in the multivariate analysis.

For analysis of associations between posture, $\mathrm{B}-\mathrm{Pb}$ and genotypes, parametric ANOVA test was used. $\mathrm{B}-\mathrm{Pb}$ and posturographic findings were then natural log-transformed (ln) to fulfill the criteria for parametric testing. Trend tests were performed by analyzing genotypes as a continuous variable, assuming a linear relationship for having zero, one or two variant alleles, in relation to $\mathrm{B}-\mathrm{Pb}$ and posture.

For further modeling, impact of explanatory variables (B-Pb, genotype and potential confounding factors) on outcome (posture), general linear models were used. The genotypes were dichotomized based on data-driven combinations of genotypes from inspection of plots of associations between posture and B-Pb, clustered for different genotypes that showed similar effects.

The statistical analyses were performed using STATISTICA 9.1 PL software (StatSoft, Inc (2010). Statistical significance was considered at $\mathrm{p}<0.05$ (two-tailed).

\section{RESULTS}

The median B-Pbs were 50 (range 26-193) and 35 (range 9-221) $\mu \mathrm{g} / \mathrm{L}$, respectively, in the two cohorts, $42 \mu \mathrm{g} / \mathrm{L}$ in the merged one.

There were significant differences in posturographic results between the two sub-cohorts (Tab. 2). For the merged cohort, the median sway area was $185 \mathrm{~mm}^{2}$ (geometric mean=GM $82 \mathrm{~mm}^{2}$; range $\left.0-2,040\right)$ and the sway velocity $13.2 \mathrm{~mm} / \mathrm{s}$ (GM $13.4 \mathrm{~mm} / \mathrm{s}$; range 5.1-49). There were significant associations between both sway area and sway velocity and $\mathrm{B}-\mathrm{Pb}$ in the unadjusted analyses (Tab. 3). B-Pb also displayed significant associations with mother's education and her smoking during pregnancy, children's apgar score, height and weight. Further, both sway areas and velocities, on the one hand, correlated with age, height and weight, on the other. On basis of this, height (strongly correlated also with age $r_{s}=0.65, p<0.001$ ) and mother's education (inversely correlated with mother's
Table 2. Posturographic findings. All differences between cohorts were significant $(P<0.001$; Mann-Whitney test)

\begin{tabular}{|c|c|c|c|c|c|c|c|}
\hline & & \multicolumn{6}{|c|}{ Cohort } \\
\hline & & \multicolumn{2}{|c|}{ 1996-2001 } & \multicolumn{2}{|c|}{$2008-2010$} & \multicolumn{2}{|c|}{ Merged } \\
\hline & & \multicolumn{2}{|c|}{$\mathrm{N}=108$} & \multicolumn{2}{|c|}{$\mathrm{N}=231$} & \multicolumn{2}{|c|}{$\mathrm{N}=339$} \\
\hline $\begin{array}{l}\text { Posture } \\
\text { parameter }\end{array}$ & $\begin{array}{l}\text { Eye } \\
\text { mode }\end{array}$ & $\begin{array}{c}\text { Median } \\
\text { (GM) }\end{array}$ & Range & $\begin{array}{c}\text { Median } \\
(\mathrm{GM})\end{array}$ & Range & $\begin{array}{c}\text { Median } \\
\text { (GM) }\end{array}$ & Range \\
\hline \multirow{2}{*}{$\begin{array}{l}\text { Sway area } \\
\left(\mathrm{mm}^{2}\right)\end{array}$} & Open & $\begin{array}{c}180 \\
(185)\end{array}$ & $38-1,220$ & $\begin{array}{c}57 \\
(55.8)\end{array}$ & $7-1,080$ & $\begin{array}{l}102 \\
(82)\end{array}$ & $7-1,250$ \\
\hline & Closed & $\begin{array}{c}304 \\
(320)\end{array}$ & $67-2,040$ & $\begin{array}{c}93 \\
(11.8)^{\mathrm{a}}\end{array}$ & $0-1,280$ & $\begin{array}{c}185 \\
(156)^{\mathrm{a}}\end{array}$ & $0-2,040$ \\
\hline \multirow{2}{*}{$\begin{array}{l}\text { Sway } \\
\text { velocity } \\
(\mathrm{mm} / \mathrm{s})\end{array}$} & Open & $\begin{array}{c}11.2 \\
(10.8)\end{array}$ & $5.8-29.7$ & $8.0(8.3)$ & $3.8-32.3$ & $9.0(9.0)$ & $3.8-32.3$ \\
\hline & Closed & $\begin{array}{c}15.1 \\
(15.7)\end{array}$ & $6.4-42.6$ & $\begin{array}{c}11.8 \\
(12.4)\end{array}$ & $5.1-49.0$ & $\begin{array}{c}13.2 \\
(13.4)\end{array}$ & $5.1-49.0$ \\
\hline
\end{tabular}

${ }^{\text {a }}$ One result $=0$ was set to 0.0001 in order to calculate GM. It changed the median value to 95.0 in the 2008-2010 and 186 in the merged cohort.

smoking during pregnancy, $\left.\mathrm{r}_{\mathrm{s}}=-0.26, \mathrm{p}<0.001\right)$ were selected for adjustments in the multivariate tests.

In the multivariate analyses, both posture parameters increased significantly with rising B-Pb (Tab. 4, Fig. 1). Such effects were present in both children with $\mathrm{B}-\mathrm{Pb} \leq 50 \mu \mathrm{g} / \mathrm{L}$ and $>50 \mu \mathrm{g} / \mathrm{L}$; the slope was significantly steeper in children with $\mathrm{B}-\mathrm{Pb} \leq 50 \mu \mathrm{g} / \mathrm{L}$. The slopes differed statistically significantly for sway area with both open and closed eyes and sway velocity with eyes open, but not fully so with closed eyes (Tab. 4).

There were no significant differences in $\mathrm{B}-\mathrm{Pb}$, neither for $A L A D$, nor $V D R$ genotypes, as previously published [11]. There were no significant main effects on posture parameters by $A L A D$ or $V D R$ genotypes. There were no significant associations between genotypes and the socioeconomic factors (not in table).

Sway area was selected for further analysis of potential modification of the relationship between posture and $\mathrm{B}-\mathrm{Pb}$ (Tab. 5). There was a significant modification by VDR FokI - ff carriers tended to have higher sway area (Figure 2). Sway velocity displayed the same pattern (Tab. 5). No other VDR polymorphism, neither $A L A D$ ones, significantly modified the relationship between posture and $\mathrm{B}-\mathrm{Pb}$.

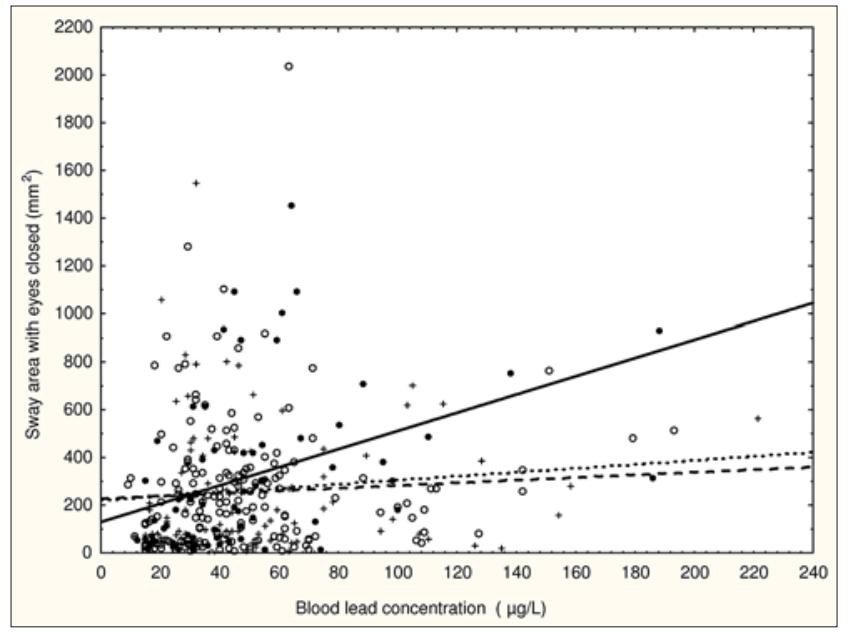

Figure 2. Relationship between sway area tested with closed eyes and blood lead concentrations (B-Pb). Modifications of VDR Fokl genotype: ff: closed dots, full line; Ff: open dots, dashed line; FF: crosses, dotted line. The data presented are unadjusted 
Table 3. Associations (Spearman's rank coefficients) in the merged cohorts between posturographic parameters, blood-lead concentrations (B-Pb) and potential confounders, effect modifiers and exposure-independent covariates

\begin{tabular}{|c|c|c|c|c|c|c|c|c|c|}
\hline & $\begin{array}{l}\text { Mother's } \\
\text { Education }{ }^{\text {a }}\end{array}$ & Age & Weight & Height & $\mathrm{B}-\mathrm{Pb}$ & $\begin{array}{l}\text { Sway area } \\
\text { Eyes open }\end{array}$ & $\begin{array}{l}\text { Eyes } \\
\text { closed }\end{array}$ & $\begin{array}{l}\text { Sway velocity } \\
\text { Eyes open }\end{array}$ & $\begin{array}{l}\text { Eyes } \\
\text { closed }\end{array}$ \\
\hline Mother's education ${ }^{\mathrm{a}}$ & - & -0.026 & 0.10 & $0.11^{\#}$ & $-0.41^{* * *}$ & $-0.12^{*}$ & -0.077 & $-0.14^{* *}$ & -0.095 \\
\hline Smoking during pregnancy ${ }^{b}$ & $-0.26^{* * *}$ & -0.032 & -0.022 & -0.056 & $0.21 * * *$ & $0.16^{* *}$ & $0.15^{* *}$ & $0.20^{* * *}$ & $0.16^{* *}$ \\
\hline Sex & 0.031 & 0.057 & $0.20^{* * *}$ & $0.12^{*}$ & 0.086 & 0.056 & 0.083 & 0.053 & $0.11^{*}$ \\
\hline Birth weight & $0.15^{* *}$ & 0.010 & $0.29 * * *$ & $0.24^{* * *}$ & -0.080 & -0.015 & 0.030 & -0.0060 & 0.049 \\
\hline Apgar score & 0.056 & $0.28^{* * *}$ & $0.23^{* * *}$ & $0.27^{* * *}$ & $-0.18^{* *}$ & -0.079 & -0.073 & -0.035 & -0.036 \\
\hline Age & -0.026 & - & $0.54^{* * *}$ & $0.65^{* * *}$ & -0.065 & $-0.22^{* * *}$ & $-0.17^{* *}$ & $-0.16^{* *}$ & $-0.14^{* *}$ \\
\hline Weight & 0.089 & $0.54^{* * *}$ & - & $0.81^{* * *}$ & $-0.20^{* * *}$ & $-0.21^{* * *}$ & $-0.15^{*}$ & $-0.20 * * *$ & $-0.13^{*}$ \\
\hline Height & 0.11 & $0.65^{* * *}$ & $0.81^{* * *}$ & - & $-0.23^{* * *}$ & $-0.23^{* * *}$ & $-0.15^{* *}$ & $-0.20^{* * *}$ & $-0.11^{\#}$ \\
\hline $\mathrm{B}-\mathrm{Pb}$ & $-0.41^{* * *}$ & -0.065 & $-0.20^{* * *}$ & $-0.23^{* * *}$ & - & $0.23^{* * *}$ & $0.24^{* * *}$ & $0.18^{* * *}$ & $0.21^{* * *}$ \\
\hline
\end{tabular}

\# $\mathrm{P}=0.06,{ }^{*} \mathrm{P}<0.05,{ }^{*} \mathrm{P}<0.01, * * * \mathrm{P}<0.001$

a Primary school $=1$, Apprenticeship $=2$, Secondary $=3$, Bachelors degree $=4$, Masters degree $=5 ;{ }^{\mathrm{b}}$ yes $=1$, no $=0 ;{ }^{c}$ boys $=1$ girls $=0$

Table 4. Multivariate modeling of the relationships between posturographic parameters tested with eyes closed and blood-lead concentrations $(\mathrm{B}-\mathrm{Pb})$ in the merged cohort $^{\mathrm{a}}$

\begin{tabular}{|c|c|c|c|c|c|c|c|c|c|}
\hline \multirow[t]{2}{*}{$\begin{array}{c}\text { Posture } \\
\text { parameter }\end{array}$} & \multicolumn{3}{|c|}{$\begin{array}{l}\text { All subjects } \\
\qquad \mathrm{N}=339\end{array}$} & \multicolumn{3}{|c|}{$\begin{aligned} \mathrm{B}-\mathrm{Pb} & \leq 50 \mu \mathrm{g} / \mathrm{L} \\
\mathrm{N} & =224\end{aligned}$} & \multicolumn{3}{|c|}{$\begin{array}{c}\mathrm{B}-\mathrm{Pb}>50 \mu \mathrm{g} / \mathrm{L} \\
\mathrm{N}=115\end{array}$} \\
\hline & Intercept (U) & $\beta(\mathrm{U}$ per $\mu \mathrm{g} \mathrm{Pb} / \mathrm{L})$ & $\begin{array}{l}\text { Model } \\
\left(R^{2} a d j\right)\end{array}$ & Intercept (U) & $\beta(\mathrm{U}$ per $\mu \mathrm{g} \mathrm{Pb} / \mathrm{L})$ & $\begin{array}{l}\text { Model } \\
\left(R^{2} \text { adj }\right)\end{array}$ & Intercept (U) & $\beta(\mathrm{U}$ per $\mu \mathrm{g} \mathrm{Pb} / \mathrm{L})$ & $\begin{array}{l}\text { Model } \\
\left.\text { ( } R^{2} \text { adj }\right)\end{array}$ \\
\hline $\begin{array}{l}\text { Sway area }\left[\mathrm{mm}^{2}\right] \\
(\mathrm{PE} ; \mathrm{Cl})^{\mathrm{b}}\end{array}$ & $\begin{array}{c}7.4 \\
(5.6 ; 9.3)\end{array}$ & $\begin{array}{c}0.007 \\
(0.002 ; 0.011)\end{array}$ & $\begin{array}{c}P=0.0002 \\
(6 \%)\end{array}$ & $\begin{array}{c}6.6 \\
(4.1 ; 9.2)\end{array}$ & $\begin{array}{c}0.025 \\
(0.010 ; 0.040)\end{array}$ & $\begin{array}{c}P=0.0003 \\
(8 \%)\end{array}$ & $\begin{array}{c}6.7 \\
(3.5 ; 9.8)\end{array}$ & $\begin{array}{c}0.006 \\
(-0.0004 ; 0.013)\end{array}$ & $\begin{array}{c}P=0.24 \\
(1 \%)\end{array}$ \\
\hline $\begin{array}{l}\text { Sway velocity }[\mathrm{mm} / \mathrm{s}] \\
(\mathrm{PE} ; \mathrm{Cl})^{\mathrm{b}}\end{array}$ & $\begin{array}{c}3.0 \\
(2.4 ; 3.8)\end{array}$ & $\begin{array}{c}0.002 \\
(0.0003 ; 0.0034)\end{array}$ & $\begin{array}{c}P=0.02 \\
(2 \%)\end{array}$ & $\begin{array}{c}2.6 \\
(1.7 ; 3.6)\end{array}$ & $\begin{array}{c}0.007 \\
(0.002 ; 0.013)\end{array}$ & $\begin{array}{c}P=0.03 \\
(3 \%)\end{array}$ & $\begin{array}{c}3.2 \\
(2.0 ; 4.4)\end{array}$ & $\begin{array}{c}0.002 \\
(-0.0005 ; 0.0043)\end{array}$ & $\begin{array}{c}P=0.30 \\
1 \%\end{array}$ \\
\hline
\end{tabular}

$\beta=$ regression coefficient, $\mathrm{PE}=$ point estimate, $\mathrm{Cl}=95 \%$ confidence interval. $\mathrm{R}^{2}=$ explained variance. $\mathrm{U}=\mathrm{unit}\left(\mathrm{mm} \mathrm{m}^{2}\right.$ or $\left.\mathrm{mm} / \mathrm{s}\right)$.

Adjustments were made for height and mother's education.

${ }^{\mathrm{b}}$ Model used: In $($ sway parameter) $=\operatorname{Intercept}+\beta 1(\ln B-\mathrm{Pb})+\beta 2($ height $)+\beta 3$ (mother's education).

Table 5. Multivariate analysis of the modification by $A L A D$ and VDR genotypes on the associations between posturographic parameter and bloodlead concentration $(\mathrm{B}-\mathrm{Pb})^{\mathrm{a}}$

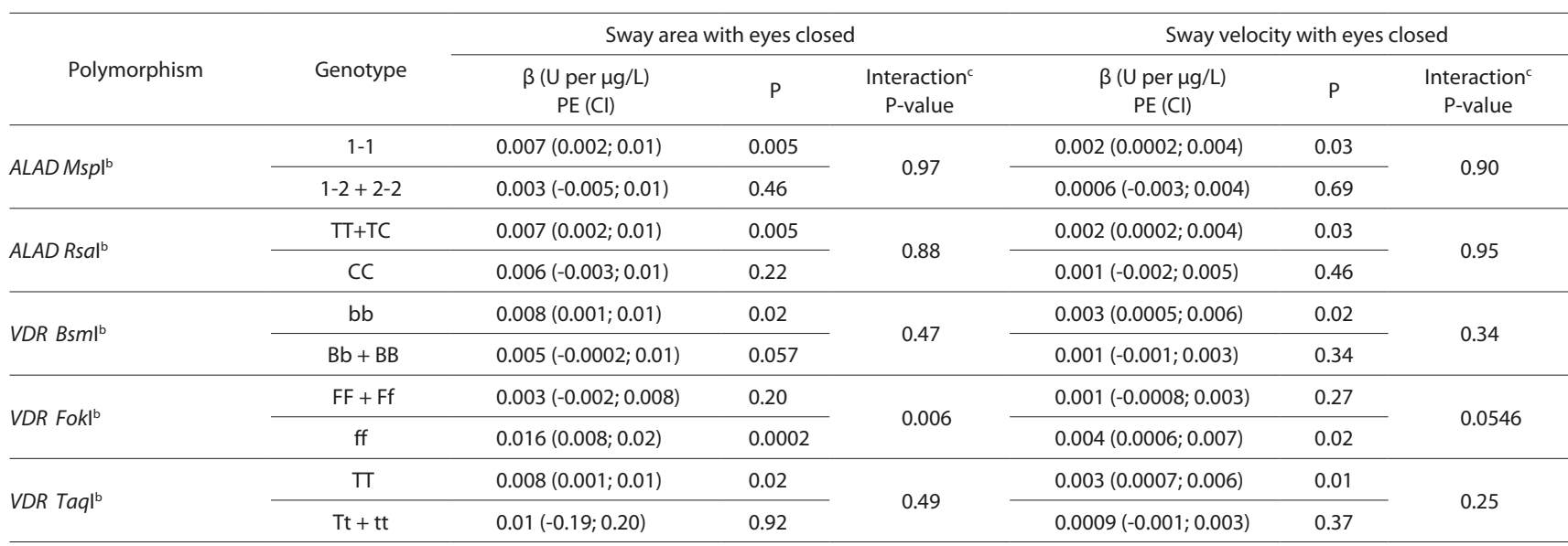

$\beta=$ regression coefficient, $\mathrm{PE}=$ point estimate, $\mathrm{Cl}=95 \%$ confidence interval

adjusted for height and mother's education

${ }^{\mathrm{b}}$ The analysis was stratified for genotype; the relationship between sway area and B-Pb for each genotype/ genotype combination is presented ( $\left.\beta 1\right)$. Model: In $($ sway area $/$ velocity) $=\operatorname{Intercept+} \beta 1(\operatorname{InB}-$ $\mathrm{Pb})+\beta 2$ (height) $+\beta 3$ (mother's education).

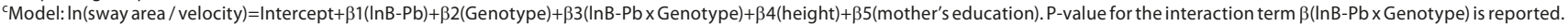

\section{DISCUSSION}

The main finding was an effect by lead exposure on posture, even at very low exposure $(\mathrm{B}-\mathrm{Pb} \leq 50 \mu \mathrm{g} / \mathrm{L})$, and furthermore, that the effect was significantly greater at such low B-Pbs than at higher. Also, VDR FokI polymorphism significantly modified the effect of $\mathrm{B}-\mathrm{Pb}$ on posture.
We included two different cohorts of children, in order to obtain a large range of exposure and more statistical power. Exactly the same methods for assessment of posture, blood sampling, lead analysis and genotyping were used in both sub-cohorts. There was a selection of children out of the original first cohort; not all could be found for new blood sampling to perform genotyping. The non-participation 
was mainly due to the fact that many of those children were now adults, and had moved out of the area. There is no reason to suspect selection as to posture, $\mathrm{B}-\mathrm{Pb}$ or genotype. Certainly, the two cohorts differed significantly in both $\mathrm{B}-\mathrm{Pb}$ and posturographic measures, but the latter was most likely because the toxic effect of lead had decreased with the reduction of exposure over time. Hence, it was judged relevant to merge the two cohorts in the final analyses.

The determinations of $\mathrm{B}-\mathrm{Pb}$ were kept under strict quality control. So, the lower levels in the second cohort are not due to a systematic bias, but to the decrease over time seen in European children, mainly because of elimination of lead from petrol. Still, our children were fairly high in a European perspective [6], probably because of remaining exposure from local lead smelters.

We have limited our main analyses to the two posturographic parameters sway area and velocity, which have usually been the most susceptible ones [23]. However, the patterns were similar for most of 24 parameters assessed.

The present first sub-cohort is part of an earlier report on the relationship between posture and $\mathrm{B}-\mathrm{Pb}$ [5]. Our findings in the second sub-cohort indicate that such effects occur at even lower B-Pbs, below those in other studies of posture in children $[1,2,3,4]$. This supports the impression that posture is a very sensitive effect outcome in studies of neurotoxicity of chemicals [1]. Indeed, it seems that toxicity by lead on posture occurs at exposures in the same exposure range as effects on cognition [14]. Interestingly, in agreement with the present effects, cognitive impairment has been reported at $\mathrm{B}-\mathrm{Pb} \leq 50 \mu \mathrm{g} / \mathrm{L}$ [25]. Also, for unknown reasons, it seems that both effects are greater per unit $\mathrm{B}-\mathrm{Pb}$ at this low exposure than at higher.

Of the total variance in posture, $2-4 \%$ was explained by $\mathrm{B}-\mathrm{Pb}$. Hence, lead may be considered to have a limited effect, as compared to other factors, like height, weight, age and socioeconomic factors, which were included in our analyses. On the other hand, on a population basis, the effect is important. Other authors suggest effects of vision impairment, drugs, medication (mainly aminoglycosides), alcohol use, right/left-handedness, middle-ear pressure $[3,5]$. We were not able to include all these in our analyses, which may have limited our total explained variance. Also, we have data only on present $\mathrm{B}-\mathrm{Pbs}$, while the postural control might be affected by earlier (and probably somewhat higher) exposure [26, 27].

Though there were obvious effects of lead exposure on the balance system, in spite of our attempts to discriminate by variations in test conditions, our data do not allow to draw firm conclusions on which part of this complex function (visual, proprioceptors, vestibular) that was affected.

In a study of genetic modification of lead-induced cognitive effects [14], we employed the same cohorts of children. We then reported the gene frequencies, which were in accordance with expectations, and that the $\mathrm{B}-\mathrm{Pb}$ in subjects with different genotypes did not differ. However, to support the interpretation of the present data, we still repeat the same information in the present paper. For a detailed discussion, including mechanistic aspects, we refer to the previous paper.

In particular because of the limited impact of lead, it is statistically demanding to demonstrate a genetic modification of the effect. Also, due to the rather limited number of children, there is a power problem, in particular for $A L A D$ $M s p \mathrm{I}$, for which the variant genotype is quite rare. For $A L A D$
$R s a \mathrm{I}$ and $V D R$, the gene frequencies are more favorable from a statistical power point of view.

Still, we found a significant modification VDR FokI on the relationship between posture and $\mathrm{B}-\mathrm{Pb}$, while there was no significant effect modification by VDR BsmI and TaqI, neither $A L A D M s p I$ or RsaI. VDR is a ligand-regulated transcription factor and the influence of $V D R$ on lead-related damage on the balance system may be due to the well-known interaction between lead and calcium, which is crucial for nervous cells. VDR FokI is located in the translation start of exon 2. The f allele produces a longer protein, with less transcriptional activity compared to the $\mathrm{F}$ allele, which may result in attenuated effect of vitamin $\mathrm{D}$ on calcium turnover and more toxic effects of lead on the CNS [28]. The frequencies of the $\mathrm{f}$ allele in European and Asian populations range $0.34-0.44$ (in our study 0.46 ), while the lowest frequencies are in Africa (0.17-0.25) [29].

Only one earlier other study has analyzed the effect of genetic polymorphism on the association between posture and $\mathrm{B}-\mathrm{Pb}$; there were then some indications of modification by VDR TaqI, dopamine receptor D2 (DRD2-A) and $N$-acetyltransferase 2 (NAT2), in 82 children, but at ten times higher lead exposure than in our children; $A L A D$ was not assessed [26]. There are also indications of a modification of other aspects of CNS toxicity by VDR TaqI [22]. We could not verify such an effect. However, the authors report fairly briefly their results.

We did not find significant effect modification by $A L A D$ MspI or RsaI, in spite of the fact that genetic modification by $A L A D$ MspI polymorphism of the toxicity of lead on CNS $[15,17,18]$ and peripheral nerves [13], as well as by $A L A D$ RsaI $[14,16]$ of lead effects on other functions of CNS than posture have been reported. However, the over-all pattern is complex.

\section{CONCLUSIONS}

We show an inverse effect by lead on posture, even at very low exposure level present in many developed countries, and furthermore, that the effect is greater at low than at higher $\mathrm{B}-\mathrm{Pb}$. The ff carriers in VDR FokI polymorphism were more susceptible to the effect of lead on the balance system.

\section{Abbreviations}

ALAD - $\delta$-aminolevulinic acid dehydratase, $\mathrm{B}-\mathrm{Pb}-$ Bloodlead concentration, CNS - Central nervous system, VDR - Vitamin D receptor

\section{Acknowledgements}

The study was supported by Polish Ministry of Science, the Swedish Council for the Working Life and Social Research, the Medical Faculty of Lund University, the county councils of Southern Sweden, and the European Union (EU; FP6; PHIME; FOOD-CT-2006-016253). The paper reflects only the authors' views; the EU is not liable for any use that may be made of the information.

The authors declare that they have no competing interests.

Technical assistance with genotyping was given by Mrs Karin Paulsson and Mrs Elżbieta Olewińska. We thank Mr Aleksander Jędrzejczak and Dr Adam Prokopowicz for the skilful lead analyses. 


\section{REFERENCES}

1. Bhattacharaya A. Quantitative posturography as an early monitoring tool for chemical toxicity. In: Quehee S. Biological Monitoring An Introduction, John Wiley \& Sons Inc. 1993.p. 421-435.

2. Bhattacharaya A, Shukla R, Auyang ED, Dietrick KN, Bornschein R. Effect of succimer chelation therapy on postural balance and gait outcomes in children with early exposure to environmental lead. Neurotoxicology 2007; 28: 686-695.

3. Després C, Beuter A, Richer F, Poitras K, Veilleux A, Ayotte P, et al. Neuromotor functions in Inuit preschool children exposed to $\mathrm{Pb}, \mathrm{PCB}$ and Hg. Neurotoxicol Teratol. 2005; 27: 245-257.

4. Frazer S, Muckle G, Després C. The relationship between lead exposure, motor function and behaviour in Inuit preschool children. Neurotoxicol Teratol. 2006; 28: 18-27.

5. Pawlas K, Pawlas N, Kmiecik-Malecka E, Malecki A. The relationship between children's blood lead level and postural stability. J Hum Kinetics. 2008; 20: 71-80.

6. Hruba F, Stromberg U, Cerna M, Chen C, Harari F, Harari R, et al. Blood cadmium, mercury, and lead in children: An international comparison of cities in six European countries, and China, Ecuador, and Morocco. Environment International. 2012; 41: 29-34.

7. Finkelstein Y, Markowitz ME, Rosen JF. Low-level lead-induced neurotoxicity in children: an update on central nervous system effects. Brain Res Rev. 1998; 27: 168-176.

8. Toscano CD, Guilarte TR. Lead neurotoxicity: from exposure to molecular effects. Brain Res Rev. 2005; 49: 529-554.

9. Caylak E, Halifeoglu I, Aydin S, Telo S, Bulmus O, Celik H. The effects of sulfur-containing compounds on total antioxidant capacity levels of liver, kidney and brain in lead-exposed rats. Turkiye Klinikleri Journal of Medical Sciences. 2007; 27: 823-828.

10. Nordberg GF, Gerhardsson L, Broberg K, Mumtaz M, Ruiz P, Fowler BA. Chapter 7. Interactions in Metal Toxicology. In: Nordberg GF, Fowler BA, Nordberg M, Friberg LT. Handbook on the Toxicology of Metals. Academic Press, Elsevier, 2007.p. 117-145.

11. Scinicariello F, Murray HE, Moffett DB, Abadin HG, Sexton MJ. Lead and -aminolevulic acid dehydratase polymorpshism: Where does it lead? A meta-analysis. Environ Health Perspect. 2007; 115: 35-41.

12. Zhao Y, Wang L, Shen HB, Wang ZX, Wei QY, Chen F. Association between delta-aminolevulinic acid dehydratase (ALAD) polymorphism and blood lead levels: a meta-regression analysis. J Toxicol Environ Health A. 2007; 70: 1986-1994.

13. Zheng G, Tian L, Liang Y, Broberg K, Lei L, Guo W, et al. $\delta$-aminolevulinic acid dehydratase genotype predicts toxic effects of lead on worker's peripheral nervous system. Neurotoxicology 2011; 32: 374-382.

14. Pawlas N, Broberg K, Olewińska E, Prokopowicz A, Skerfving S, Pawlas K. Modification by the genes ALAD and VDR of lead-induced cognitive effects in children. Neurotoxicology 2012; 33: 37-43.

15. Weuve J, Kelsey KT, Schwartz J, Bellinger D, Wright RO, Rajan P, et al. Delta-aminolevulinic acid dehydratase polymorphism and the relation between low level lead exposure and the Mini-Mental Status
Examination in older men: the Normative Aging Study. Occup Environ Med. 2006; 63: 746-53.

16. Chia SE, Huijun Z, Theng TM, Yap E. Possibilities of newer ALAD polymorphism influencing human susceptibility to effects of inorganic lead on the neurobehavioral functions. Neurotoxicology. 2007; 28: 312-317.

17. Krieg EF Jr, Butler MA, Chang MH, Liu T, Yesupriya A, Lindegren $\mathrm{ML}$, et al. Lead and cognitive function in ALAD genotypes in the third National Health and Nutrition Examination Survey. Neurotoxicol Teratol. 2009; 31: 364-371.

18. Gao A, Lu XT, Li QY, Tian L. Effect of the delta-aminolevulinic acid dehydratase gene polymorphism on renal and neurobehavioral function in workers exposed to lead in China. Sci Tot Environ. 2010; 408: 4052-4055.

19. Rezende VB, Barbosa F Jr, Montenegro MF, Sandrim VC, Gerlach RF, Tanus-Santos JE. Haplotypes of vitamin D receptor modulate the circulating levels of lead in exposed subjects. Arch Toxicol. 2008; 82: $29-36$

20. Schwartz BS, Lee BK, Lee GS, Stewart WF, Simon D, Kelsey K, et al. Associations of blood lead, dimercaptosuccinic acid chelatable lead, and tibia lead with polymorphisms in the vitamin D receptor and [delta]aminolevulinic acid dehydratase genes. Environ Health Perspect. 2000; 108: 949-954

21. Haynes EN, Kalkwarf HJ, Hornung R, Wenstrup R, Dietrich K, Lanphear BP. Vitamin D receptor Fok1 polymorphism and blood lead concentration in children. Environ Health Perspect. 2003; 111: 1665-1669.

22. Krieg EF Jr, Butler MA, Chang MH, Liu T, Yesupriya A, Dowling $\mathrm{N}$, et al. Lead and cognitive function in VDR genotypes in the third National Health and Nutrition Examination Survey. Neurotoxicol Teratol. 2010; 32: 262-272.

23. Deprés C, Lamoureux D, Beuter A. Standardization of a neuromotor test battery: the CATSYS system. Neurotoxicology 2000; 21: 725-35.

24. Stoeppler M, Brandt K, Rains TC. Contribution to automated trace analysis. Part II. Rapid method for the automated determination of lead in whole blood by electrothermal atomic-absorption spectrophotometry. Analyst. 1978; 103: 714-722.

25. Lanphear BP, Hornung R, Khoury J, Yolton K, Baghurst P, Bellinger DC, et al. Low-level environmental lead exposure and children's intellectual function: an international pooled analysis. Environ Health Perspect. 2005; 113: 894-899.

26. Chakraborty BM, Lee HS, Wolujewicz M, Mallik J, Sun G, Dietrich KN, et al. Low dose effect of chronic lead exposure on neuromotor response impairment in children is moderated by genetic polymorphisms. J Hum Ecol. 2008; 23: 183-194.

27. Ratzon N, Froom P, Leikin E, Kristal-Boneh E, Ribak J. Effect of exposure to lead on postural control in workers. Occup Environ Med. 2000; 57: 201-203.

28. Uitterlinden AG, Fang Y, van Meurs JBJ, Pols HAP, van Leeuwen JPTM. Genetics and biology of vitamin D receptor polymorphisms. Gene 2004; 338: 143-156.

29. www.ncbi.nlm.nih.gov/projects/SNP (access: 2013.04.03). 